\title{
CENTAUROS E GAÚCHOS - O SURGIMENTO DA FIGURA MÍTICA “CENTAURO DOS PAMPAS"
}

\author{
CENTAURS AND GAUCHOS - THE EMERGENCE OF THE \\ MYTHICAL FIGURE "CENTAUR OF THE PAMPAS"
}

\section{Dóris Helena Soares da Silva Giacomolli ${ }^{1}$}

\begin{abstract}
Resumo: O processo de formação da imagem do gaúcho sul-rio-grandense está estreitamente relacionado com o cavalo, o que culminará na aproximação definitiva de sua imagem à figura desse animal. O homem do pampa, inseparável dos cavalos, se cristaliza na cultura popular. Esse trabalho ressalta a importância da literatura na consolidação dessa relação entre a figura do gaúcho e o mito do centauro, pois ainda que o surgimento dessa concepção não se dê na literatura e sim no processo de formação da imagem do gaúcho, o que antecede à literatura gauchesca, a literatura imortaliza essa percepção. Dessa aproximação entre os centauros e gaúchos surgirá, então, uma criatura mitificada, estilizada e cultuada na literatura fazendo surgir expressões como "Rio Grande a cavalo" e "centauro dos pampas". Este trabalho estabelecerá esta e outras relações entre o personagem Capitão Rodrigo de "Um certo Capitão Rodrigo" de O continente primeiro volume da trilogia $O$ tempo e o vento, texto épico regional do escritor Erico Verissimo e a figura mitológica, o centauro. $\mathrm{O}$ artigo pretende deter-se especialmente nas relações de sexualidade, luxúria, violência, embriaguez, instinto bestial e ações irracionais do Rodrigo Cambará que o fazem aproximar-se irremediavelmente do centauro, criatura resultante do estupro da nuvem Nephele, na antiga Grécia.
\end{abstract}

Palavras-chave: Gaúcho; Centauro dos pampas; Rodrigo Cambará; Erico Verissimo.

Abstract: The process of image formation of Rio Grande do Sul is closely related to the horse, which will culminate in the definitive approximation of his image to the figure of this animal. The man of the pampa, inseparable from the horses, crystallizes in popular culture. This work underscores the importance of literature in the consolidation of this relationship between the Gaucho figure and the centaur myth, because although the emergence of this conception does not occur in the literature but in the process of the image formation in the gaucho, which precedes the gauchescaliterature; literature immortalizes this perception. From this approach between the centaurs and the gauchos will appear a mythical creature, stylized and worshiped in the literature giving rise to expressions such as "Rio Grande on horseback" and "centaur of the pampas". This work will establish this and other relations between the character Captain Rodrigo of "A certain Captain Rodrigo" of The continent first volume of the trilogy Time and the wind, regional epic text of the writer Erico Verissimo and the mythological figure, the centaur, stressing specially in the relations of sexuality, lust, violence, drunkenness, bestial instinct and Rodrigo Cambará's irrational actions that makes him approach irremediably to the centaur, creature resulting from the rape of the Nephele cloud in ancient Greece.

Keywords: Gaucho. Centaur of the pampas. Rodrigo Cambará. Erico Verissimo.

\section{Introdução}

Este texto pretende analisar aspectos referentes à sexualidade e impetuosidade do Capitão

\footnotetext{
${ }^{1}$ Doutoranda em História da Literatura - FURG e doutoranda em Estudos de Literatura e História - UFPEL. Professora no Estado do Rio Grande do Sul. https://orcid.org/0000-0001-5699-0523; http://lattes.cnpq.br/ $\underline{7121110420173190}$
}

https://periodicos.unifap.br/index.php/letras

Macapá, v. 9, n. 2, $2^{\circ}$ sem., 2019 
Rodrigo, personagem de "Um certo Capitão Rodrigo" de O continenente, primeiro volume da trilogia $O$ tempo e o vento, texto épico regional do escritor Erico Verissimo ${ }^{2}$.

No século XIX, havia muitas fazendas de gado e necessidade de defender a terra e a fronteira. Esse trabalho era realizado pelo gaúcho, adjetivo gentílico o qual conjuga ao mesmo tempo a ideia do homem que anda a cavalo e do peão que faz o trabalho das fazendas e estâncias. A maioria dos autores rio-grandenses diz que o termo gaúcho seria uma corruptela da palavra Huagchu, de origem quéchua, traduzida por guacho, que significa órfão e designaria os filhos de índia com branco português ou espanhol. O gaúcho é um tipo social que se originou a partir da miscigenação que ocorreu no Rio Grande do Sul. Reichel, (2000) nos fala da relevância do texto de Erico Verissimo para o processo de construção de uma sociedade e para a afirmação da identidade coletiva, mas para que as "[r]epresentações de um romancista, aqui entendidas como construções mentais subjetivas apresentadas de forma ficcional, sem compromisso com a objetividade do real, alcancem o estatuto da verdade e atuem como marcas identitárias, é necessário que dois elementos se conjuguem.” (REICHEL, 2000, pp. 207-208)

A pesquisadora diz que esses dois elementos devem fazer parte do imaginário de quem os recebe, isto é, deve ser reconhecido pelos membros do grupo que recebe o discurso do autor, como se ele fosse uma autoridade, já que "deve haver uma relação entre a narrativa do enunciador e as vivências econômicas, sociais políticas e cultuais do grupo receptor."(REICHEL, 2000, p. 208) O texto contribui para a constituição da identificação com as representações veiculadas se atuar na constituição de pertinência e alteridade, se expressar conceitos, juízos e comportamentos incorporados e reconhecidos; "todo grupo tem a necessidade de conhecer sua origem, aquelas representações vão desempenhar esse papel tanto quanto mais estiverem compromissados a dar conhecimento das condições de nascimento do próprio grupo" (REICHEL, 2000, p. 208)

No discurso de Erico Verissimo e na construção de O tempo e o Vento, a construção do personagem capitão Rodrigo Cambará foi aceito como verossímil, como uma figura relacional do imaginário do Rio Grande do Sul, pois "o romance de Erico pode ser considerado como um discurso regionalista que contribui significativamente para a aceitação coletiva de determinadas representações como sendo próprias da identidadesul-rio-grandense.” (REICHEL, 2000, p. 208). Quando essa autora escreve sobre a origem e a formação dos gaúchos, sobre o comportamento guerreiro de um combatente de várias guerras, não há como não contribuir de maneira decisiva e categórica "no processo de construção de sua identidade" (REICHEL, 2000, p. 209).

\section{Gaúcho}

O gaúcho aparece, na literatura, como um trabalhador do campo e também como uma espécie de soldado, ligado à atividade pecuária; o termo é correntemente usado para a denomina-

\footnotetext{
2 Um certo capitão Rodrigo" faz parte de O continente. Foi publicado em 1949, abrindo a trilogia que Erico Verissimo denominou $\mathrm{O}$ tempo e o vento. Quando lançou o romance, talvez o escritor não soubesse que seriam necessárias três obras diferentes para dar conta do tema que escolhera, mas, quando termina o primeiro deles, já anuncia sua continuação, O retrato, editado em 1951. Apesar de pertencer ao conjunto completado apenas em 1962, quando aparece o terceiro volume de $\mathrm{O}$ arquipélago, $\mathrm{O}$ continente tem unidade própria e pode ser lido como livro independente. A obra divide-se em sete segmentos, sendo que um deles, "O sobrado", emoldura todos os outros. É também o trecho que se apresenta fragmentado, porque a ação narrada não se oferece toda de uma vez, e sim aos pedaços, à medida que o leitor vai avançando no conhecimento da história da família Cambará. "O sobrado" corresponde à parte final dessa história, mas tomamos contato com ela em primeiro lugar, a sequência sendo interrompida para o narrador dar conhecimento do que se passou antes, desde os tempos mais remotos até a atualidade, representada pelo cerco da casa de Licurgo, assunto da moldura em questão. Os demais segmentos têm teor retrospectivo: "A fonte" narra a infância de Pedro, o menino que vive numa das missões jesuíticas e assiste à derrota de seu povo; "Ana Terra" centra-se na vida dessa personagem, desde o encontro com Pedro, agora adulto, até a fundação de Santa Fé, cidade onde ela se radica; "Um certo capitão Rodrigo" introduz a figura do soldado aventureiro que, com Bibiana, dá início ao clã Terra Cambará. (Fragmento extraído do prefácio escrito por Regina Zilberman para a edição de O tempo e o vento - Cia das Letras. Disponível no link: http://www.profdomingos.com. br/o continente um.pdf.
}

https://periodicos.unifap.br/index.php/letras

Macapá, v. 9, n. 2, $2^{\circ}$ sem., 2019 
ção de habitantes do estado brasileiro do Rio Grande do Sul e dos países de língua espanhola, Argentina e Uruguai, regiões de ocorrência do bioma denominado pampa, que foi descrito por José de Alencar em O gaúcho: "O pampa é o pasmo, o torpor da natureza. O viandante perdido na imensa planície, fica mais que isolado, fica opresso. Em torno dele faz-se o vácuo: súbita paralisia invade o espaço, que pesa sobre o homem...” (ALENCAR, 1973, p. 9).

O termo gaúcho aqui quer significar toda uma cultura que cinge a região platina e não somente o gaúcho brasileiro oposto ao gaúcho argentino ou uruguaio. Apesar disso, ao buscar identificar o gaúcho sul-rio-grandense, vale definir brevemente o que o diferencia do gaúcho platino uruguaio ou argentino, através uma pequena comparação entre a formação política, social e cultural do gaúcho uruguaio, sul-rio-grandense e argentino segundo a reflexão de Moysés Vellinho, O Rio Grande e o Prata: contrastes, autor de obra de 1962.

O gaúcho platino, segundo Vellinho (1962), não se proclama com a identidade do gaúcho rio-grandense visto que as raízes formadoras dos dois diferem. Há pontos de parecença devido às atividades do pastoreio e de ambos viverem no pampa, cenário físico análogo, fatores que os assemelham. A colonização espanhola deu-se através de meios violentos, de extrema violência e crueldade, estabelecendo oposição dos naturais platinos. Os espanhóis serviam-se das nativas gerando uma população híbrida no país, párias excluídos da sociedade espanhola que se formava: "À sombra de violências e rancores surdiria das ervas esse elemento de raivosa pugnacidade: o mestiço." (VELLINHO, 1962, p.13) Não havendo lugar para esses mestiços na vida social e política da Colônia, uniram-se aos nativos. Aproximava-os um sentimento comum de hostilidade contra a soberbia espanhola, visto que "fora da satisfação dos instintos, que nada tem a ver com preconceitos raciais em sociais, o espanhol não admitia nenhum entendimento com a arraiamiúda. (VELLINHO, 1962, p. 18)

Vellinho (1962) justifica o menosprezo espanhol aos nativos ao fato de que não podendo sustentar na colônia brasões legítimos, estendiam aos nativos, mestiços e crioulos um cordão de isolamento para mantê-los à distância, "preservar de contaminações espúrias a limpidez de sua extração". (VELLINHO, 1962, p.21) Dessa forma, mal vistos e repudiados, refugiavam-se nos pampas. O contingente aumentava com os desertores dos fortins que iam juntar-se a eles, nos campos desertos da Argentina. A hostilidade contra o espanhol que chegava, fez com que se estabelecesse entre mestiços e indígenas um anseio espontâneo de cooperação, que se apoiava no desejo de vingança. Vellinho (1962) afirma que esses homens, o mestiço argentino, o gaúcho em estado bruto, descende em "linha reta daqueles gaudérios" (p. 24) e iriam formar, após a Independência, o caudilhismo em que grandes senhores de terra faziam prevalecer seus direitos acima dos outros de qualquer maneira. Vellinho (1962) nos diz que as "rasas campanhas uruguaias, por sua vez, embora disputadas e em parte ocupada pela coroa de Portugal, foram durante muito tempo apenas como uma estância de Buenos Aires, (VELLINHO, 1962, p. 25). Há, entre o gaúcho uruguaio e argentino, muitas semelhanças e diferenças, mas o que mais se acentua é o traço comum de ressentimento contra a civilização, um estado de rebelião do caudilho contra a cidade.

O Rio Grande do Sul integrou-se tardiamente ao restante do Brasil colonial. Foi descoberto no início do séc. XVI, a partir de expedições litorâneas de exploração e comércio "[d]essas viagens resultaram registros e descrições da costa gaúcha, assim como a generalização do nome "Rio Grande de São Pedro" para toda a área." (PESAVENTO, 1982, p. 7)

Vellinho (1962) afirma que há uma diferença entre esses gaúchos e os do Rio Grande de São Pedro, como foi primeiramente chamado o Rio Grande do Sul. ${ }^{3}$ No tempo que os portugueses chegaram nestes campos, o nativo não representava numericamente e não era um fator ativo

\footnotetext{
${ }^{3}$ A Província Rio Grande de São Pedro do Sul, assim chamada porque todas as regiões do Brasil receberam um orago junto a uma toponímia, era uma região inóspita, deserta, massacrada pelo minuano, motivo pelo qual os colonizadores não vislumbravam nenhuma riqueza aproveitável. (FLORES,1986, p. 45)
} 
de civilização: $\mathrm{Na}$ formação antropológica do nosso campeiro, o índio não só entrou como um contingente bem mais pobre, como trazia a alma sem a carga de ódio, com que ele reagiu ao desprezo e à violência do espanhol, nas campanhas platinas." (VELLINHO, 1962, p.34) Havendo bom tratamento por parte dos portugueses aos poucos indígenas que restavam, ainda que a causa fosse a necessidade de aliança e amizade, para defender as fronteiras do inimigo externo, os espanhóis de Buenos Aires e Montevidéu, impediu que houvesse antagonismo entre os colonizadores portugueses e o gentio, no Rio Grande do Sul.O processo de formação do gaúcho rio-grandense deu-se, em suas origens, de forma mais pacífica que o gaúcho platino; não guardavam, os gaúchos do Rio Grande do Sul, rancores tão profundos quanto o gaúcho do Plata. Houve sim, uma acirrada cisão entre o gaúcho e os inimigos platinos que investiam pela definição de fronteiras e limites. O oponente do povo riograndense era externo, os castelhanos; a constante necessidade de defesa das fronteiras e o inimigo comum manteve unidos os rio-grandenses, tanto do interior quanto os da cidade. No Rio Grande do Sul, onde o comércio era pequeno e a indústria inexistente, houve uma união entre o campo e as cidades visto que aquele proporcionava para estas a estabilidade econômica que provinha das atividades pastoris.

\section{Gaúcho rio-grandense}

Com a chegada dos casais dos Açores, quese iniciou a partir de 1748, o Continente de São Pedro é alimentado por um incremento demográfico. Adaptando-se ao clima e à topografia, tornam-se estanceiros, mesclam-se com os castelhanos andarilhos que por aqui vagueavam sem ocupação certa, mas sabiam tropear, lidar com o gado, roubar e pelear. Em Buenos Aires, esses andarilhos eram chamados de "cuatreros e vagabundos", que roubavam e assolavam o campo. Em 1824, chegaram ao Brasil os alemães e, em 1870, os italianos. Com o caldeamento das raças, resultou um tipo humano ímpar: "o gaúcho da campanha". Em 1642, os jesuítas registraram vagabundos que pilhavam as estâncias das missões. Em 1759, foram designados de "gaudérios ou gaúchos", estes homens que circulavam pela Capitânia de Rio Grande de São Pedro.

O gaúcho do Rio Grande do Sul teve sua imagem transformada após a Revolução Farroupilha. Com o passar do tempo, sua figura foi se transformando. De pária social passou a ser protagonista e herói. O gaúcho é degradado pelo estanceiro, o dono das terras: "A revolução Farroupilha mudou tudo [...] Os campos foram cercados. A administração oficial criou as cortes de justiça. Os soldados passaram a perseguir, com auxílio dos grandes proprietários e seus asseclas, os que não quisessem aceitar o novo poder.” (HOHLFELDT, 1996, p. 26)

Hohlfeldt (1996) faz referências a esses eventos de perseguição ou absorção como mudanças que se fizeram sob uma forte pressão política e refere-se a uma "dizimação impiedosa de que era vítima o gaúcho tradicional” (HOHLFELDT, 1996, P.27) O gaúcho tradicional foi acossado e perseguido. "Se os segmentos sociais urbanos que se constituíram então, compensaram suas frustrações [...] o gaúcho comum não teve essa oportunidade.” (HOHLFELDT, 1996, p. 26)

Vellinho (1962) assim menciona o destino desses homens:

À proporção que a fronteira progredia, e as atividades pastoris passavam do regime anárquico da preia dos rebanhos selvagens ${ }^{4}$ ra natural que fossem desbordando para o sul os antigos habitantes, gente rebelde e sem paradeiro, refratária por instinto à ação de presença dos modestos padrões de estabilidade social que se iam plantando e multiplicando sob a alçada portuguesa. Bandoleiros que ficassem para trás das novas avançadas, ou por elas se insinuassem, formando bolsões errantes, tendiam a desagregar-se, ora bandeando a fronteira, ora se deixando eventualmente absorver. (VELLINHO, 1962, p. 61)

\footnotetext{
${ }^{4}$ Rebanhos que foram abandonados pelos jesuítas e indígenas que tiveram que fugir às pressas para o Uruguai: "Estes rebanhos, abandonados no pampa e reproduzindo-se à solta, tornaram-se bravios e formaram uma imensa reserva de gado, conhecida como "Vacaria del Mar". Estava lançado o fundamento econômico básico de apropriação da terra gaúcha: a preia do gado xucro.” (PESAVENTO, S. J., 1982, p. 9).
} 
Os que foram absorvidos pelas estâncias tornam-se peões: "Proletarizado na forma de peão de estância, foi obrigado a se transformar em propriedade reificada da instituição." (HOHLFELDT, 1996, p. 26) Essa visão de gaúcho como um monarca forte, conforme ela chegou ao século XX, formou-se baseada na imagem imposta pela classe dominante:

uma construção ideológica dos grupos dominantes, compostos principalmente por estancieiros e líderes políticos, que encobria os problemas sociais do trabalhador rural, principalmente da região da Campanha, nas áreas fronteiriças com a argentina e o Uruguai, onde, historicamente, se desenvolveu a atividade pecuária. É nesse cenário que o mito do gaúcho-herói, na figura do peão de estância, surgiu e exerceu seu papel principal no trabalho com o gado e na defesa do território contra o invasor castelhano, assim visto pelos luso-brasileiros, o que propiciou, por conseguinte, a formação do binômio peão-guerreiro. O gaúcho viveu, por longo tempo, dentro de uma atmosfera de lutas, conflitos e guerras, desenvolvendo predominantemente, as lides do campo e do pastoreio, influências marcantes do seu caráter. O monarca das coxilhas nada mais é do que o herói desses tempos primordiais da história rio-grandense. O gaúcho monarca, independente da ideologia a que serve e da condição social de quem o observa, seduz pelo arquétipo que representa: o homem livre, dono de si, altivo, orgulhoso de sua natureza, nobre, conhecedor de seu meio, hábil em seu ofício de campeiro e corajoso. É um exemplo de ou uma referência de ser e viver a vida: um mito. (DANIEL, 2007, pp. 30 31)

Essa imagem que encobria os problemas sociais serviu à estrutura de dominação nas relações de poder detectadas no espaço social da estância, que glorificava os grandes fazendeiros, senhores gaúchos latifundiários, cheios de poder, que ajudaram a definir um tipo social e que os peões das fazendas queriam seguir e copiar; um modelo heroico propagado pela ideologia senhorial com o objetivo de seduzir e fazer com que o homem trabalhador do campo o almejasse alcançar: "A guerra civil acentuou o espírito regionalista dos rio-grandenses e se transformou num símbolo de identidade na construção da memória. No fim do império, tanto o Partido Liberal, como o Republicano usaram a Guerra Civil dos Farrapos para dizerem que eram continuadores de seus ideais." (FLORES, 2004, p. 15)

Se os grandes proprietários também ajudaram a forjar o tipo ideal de gaúcho, este tinha muito da altivez daqueles:

Essa visão de gaúcho, conforme ela chegou ao século XX, formou-se baseada na imagem imposta pela ideologia senhorial, pela estrutura de dominação nas relações de poder detectadas no espaço social da estância, que glorificava os grandes fazendeiros, senhores gaúchos latifundiários, cheios de poder, que ajudaram a definir um tipo social e que os peões das fazendas queriam seguir e copiar. Cabia, pois, ao romancista descobrir como eram "por dentro", os homens da campanha do Rio Grande. Era com aquela humanidade batida pela intempérie, suada, sofrida, embarrada, terra-a-terra, que eu tinha que lidar quando escrevesse o romance do antigo Continente. (VERISSIMO, 1980, p. 291)

Surgiu, então, uma criatura idealizada, construída sobre os restos do antigo andarengo. A figura do gaúcho foi alimentada e enriquecia por uma legenda; ia projetar-se no tempo e ganhar espaço, já agora liberta de seus caracteres primitivos, e acabaria, como uma espécie de mimetismo sociológico, absorvendo na sua estrutura moral todos os rio-grandenses identificados com a terra não só por filiação histórica, mas ainda por aculturação ou adesão afetiva. (VELLINHO, 1962, p.118)

Do ponto de vista do rio-grandense, gaúcho é uma palavra que carrega consigo a história de um povo; ela vem impregnada de significação; "o gaúcho, desde o início, aparece com fortuna desigual, ora se apresenta como herói, como monarca forte, livre e valente, ora como andarengo, marginalizado, de pé no chão, perambulando de fazenda em fazenda." (MAROBIN, 1985. p. 91)

A origem da palavra "gaúcho" tem muitos segmentos. Erico Verissimo (1980) fala dessa forma da riqueza de tipo que forma o gaúcho: "o Rio Grande estava cheio dos mais variados tipos humanos. havia o valentão, o coronel, o peão, o gaudério, o bandido, o paladino, o gaiato, o 
capanga, o sisudo, o potoqueiro, o gaúcho da cidade com flor no peito... tantos!" (VERISSIMO, 1980, p.291)

O termo se originou de uma forma própria de interpretar e reinventar o homem que existia. Segundo alguns autores, provém do guarani e significaria "homem que canta triste", aludido provavelmente à "cantilena arrastada dos minuanos". Gostava do jogo, não levava desaforo de ninguém e seu código de honra incluía vingança. A mulher, em geral, servia-lhe apenas como fêmea, podendo ser facilmente substituída por algum animal. Não desrespeitava a mulher, mas não a valorizava. Entre a mulher e um cavalo, certamente ficava com este último. (HOHLFELDT, 1996, p. 26) comenta:

Essa origem está representada na obra O continente: "se lemos o início de O continente [...] assistimos ao nascimento de Pedro Missioneiro [...] filho de uma índia currada por algum homem branco[...] Bem mais adiante vamos encontrar o célebre Capitão Rodrigo que, indagado de suas origens, tudo sintetiza com um ser "filho das macegas", e nada mais. (HOHLFELDT, 1996, p. 19)

A construção do gaúcho mítico partiu do real e se tornou plausível com referenciais históricos, passando, no decorrer do tempo, a ser considerada como conhecida de todos, embora seja uma criação que se processou lentamente, até se tornar anônima, formando uma tradição de geração em geração. Em pouco tempo, o mito se confunde com tradição, sendo aceito por todos porque a narrativa usa matrizes sociológicas do trabalho campeiro, na camaradagem galponeira e na turbulência das antigas revoluções e lutas na fronteira. (FLORES, 2004, p. 2)

O habitante do Rio Grande do Sul foi mitificado com a ajuda da literatura. A partir do Romantismo e do herói romântico, ${ }^{5}$ criaram-se personagens à inspiração europeia, que ajudaram a modificar a acepção pejorativa do termo e homem gaúcho: “[...] Íntegro, sem crises, sem defeitos, o tipo de gaúcho, dessa fase, fixa os traços básicos do "monarca das coxilhas" que, para ser grande, sempre necessitou de adversários, de guerras, de companheiros de luta. Mas, a exaltação do símbolo e do mito andou muito próxima da mistificação.” (MAROBIN, 1985. p.67)

Este herói não existiu de fato, plenamente, mas foi, de certa forma, criado pela literatura, que, para isso, aproveitou-se do homem que vivia nos campos, quando da formação do Rio Grande do Sul, o mesclou com a figura dos grandes proprietários de terras e criou uma figura ficcional de cavaleiro forte e invencível, honrado e valente: "O gaúcho antigo, que desaparecia como tipo social contudo, gradualmente, transmutava-se enquanto herói artístico, notadamente na literatura." (HOHLFELDT, 1996, p. 27)

Luiz Marobin (1985) assim define o que significa mito: "Mito vem de Mythos, fabulação de algo maravilhoso [...] é uma irrupção do sobrenatural. Ou encarnação, personificação de forças misteriosas da natureza." (p. 38) Os mitos e lendas de uma terra servem à literatura e a literatura se serve deles para criar personagens. Depois esses personagens ajudam a fortalecer e a fomentar de maneira mais expressiva: "formam um lençol arquétipo, do qual os escritores retiram importantes estratos de suas narrativas e fabulações" e entre o que é mito e o que é realidade se "revelam surpreendentes analogias". (MAROBIN, p. 40) e ajudam a formar a história do Rio Grande do Sul: "Em termos concretos, a literatura do Rio Grande do Sul não é nem história, nem pura fantasia. No entanto, a realidade gaúcha e o mundo imaginário, suprarreal não estão alheios nas letras dos pampas. No começo era o mito [...] Por fim a encarnação, a personificação, o mito, e naturalmente a literalidade." (MAROBIN, 1985, pp. 40-41)

O morador do Rio Grande do Sul adotou esses personagens como seus ascendentes: "À proporção que a imagem primitiva recua, a outra se renova e cresce, e já se confunde com a alma da coletividade nos seus melhores assomos." (VELLINHO, 1962, p.119); acabou transformandose, ele mesmo, em monarca da coxilha, um homem, temerário, audaz, corajoso, leal e libertário:

\footnotetext{
${ }^{5}$ Herói romântico: herói idealizado, possuía coragem, postura idealista, desejo de justiça e moral. O sentimento das personagens e os conflitos destes são mostrados na prosa e há também uma ideia muito forte de bem contra mal, verdade contra mentira, moral versus imoralidade. (COUTINHO, 1955, 89).
} 
Era um gaúcho que se importava com suas leis, puro de caráter e que não se corrompia na cidade. Esse gaúcho era um homem de palavra, com habilidades no campo, do qual tirava o seu sustento, um homem de vida simples, que herda de seu berço todos esses seus valores. Daí a ideia de "Monarca". Essa forma de ver o gaúcho identifica o espírito romântico de quem o descrevia, bem como a oligarquia vigente no sul. (SILVA E SANTOS, 2005, p. 3).

Esse mito, os motivos da importância da figura mítica no inconsciente social do povo gaúcho, a necessidade de criação de uma identidade e à negação da sua própria, já que "para ter um pequenino círculo de terra prestava serviço de vassalagem na melhor tradição medieval" (HOHLFELDT, 1996, p. 26) exerceu um importante papel na formação identitária do povo do Rio Grande do Sul tornando-se uma verdade mais aceitável e preferível. O rio-grandense precisava de um senso de autoafirmação que era um povo em conflito entre o que era e o que desejava ser, ainda sem consciência de quem era ou a quem pertencia: "O gaúcho antigo [...] surgia transformado: a elite dominadora, que criara as instituições capazes de legitimar seu discurso, buscava transferir para a literatura, com a conivência calada à força das personagens populares, sua própria imagem: a da democracia estancieira, onde proprietário e propriedade se identificavam." (HOHLFELDT, 1996, p.27)

Grande parte do povo gaúcho exalta a coragem de seus ancestrais, canta seu apego à terra e seu grande amor pela liberdade. Hoje, gaúcho é mais um mito que realmente uma classe social, mas ainda carrega uma conotação ligada ao machismo, a um padrão de masculinidade, apesar de já não ser mais tão forte como no contexto da colonização do Rio Grande e nos tempos das guerras: "De início, a exaltação do herói, do centauro das coxilhas, do monarca das coxilhas, onde tudo eram valentias, bravuras, fortaleza, honra e liberdade. [...] Erico Verissimo faz a síntese do equilíbrio: o gaúcho é somente gaúcho, isto é, homem social, livre e honrado. E esse existiu, existe e existirá nos pampas, nas coxilhas e nas cidades do Rio Grande." (MAROBIN, 1985, p. 251)

O mito se mantém na posteridade. Ele se constitui em um tempo primevo. É o presente que lhe dá a permanência, é o imaginário coletivo que, com o tempo, institui a mitificação; assim o mito do gaúcho/ herói se mantem vivo até hoje, não de forma totalmente natural, já que é evocado pelo povo que aqui vive e faz questão de manter viva esta tradição através de festivais de música e dança gaúcha, o culto aos CTGs e é alimentado pela mídia de diversas outras forma, mantendo o mito sempre vivo na memória gaúcha:

O mito permanece vivo no seio de algumas sociedades, porque ele é frequentemente evocado, fazendo com que a pessoa que o evoca se torne seu contemporâneo e, assim, um simples mortal passa a compartilhar da presença dos mitos fundadores, buscando neles o exemplo a seguir. O homem mantém o mito vivo, e o mito mantém o homem. É essa significação de ser sobrenatural que faz do mito substância irradiante de energia vital, que faz dele algo pertencente à ordem do sagrado, o que leva um povo a viver novamente com dignidade e esperar um destino sublime para as gerações vindouras. (DANIEL, 2007, pp.12-13)

A literatura ajudou a fortalecer o mito do gaúcho, figura ao mesmo tempo rude e valente que o trabalho braçal torna ainda mais forte, acostumada ao trabalho ao ar livre, cercada de perigos da lida e das guerras, o que lhe exigia desenvoltura e coragem, atributos essenciais a um verdadeiro herói guerreiro:

Foi com o aparecimento da Sociedade Partenon Literário, em Porto Alegre em 1868, que se começou a utilizar a figura do gaúcho mítico na literatura.[...] Cooptados pelas oligarquias do poder regional, de cujas benesses dependiam, os integrantes do grupo Partenon passaram a adequar seus referenciais estéticos aos dos interesses desse poder local, o que ocorria através da tentativa de conciliar as tendências culturais europeias com a ideologia positivista da oligarquia provinciana do final do século, e com a tentativa de aproximação entre o discurso literário e o discurso político. A literatura introduzia no mundo urbano emergente, a imagem idealizada e ideologicamente fabricada do gaúcho cumprindo a função de projetar para o centro do país, uma imagem positiva dos habitantes da província sul-rio- 
Essa imagem do gaúcho, porém, só chegou a transformar-se em mito devido à influência romântica, porque em outras épocas o gaúcho chegou a ter conotação oposta à que lhe é atribuída hoje em dia. Marobin (1985) refere-se à imprecisão e à dubiedade das primeiras imagens formadoras do gaúcho, já que o adjetivo formou-se a partir de figuras controversas: "O gaúcho, desde o início, aparece com fortuna desigual. Ora se apresenta como herói, como monarca forte, livre e valente, ora como andarengo, marginalizado, de pé no chão, perambulando de fazenda em fazenda." (MAROBIN, 1985, p. 91)

A mítica em torno do gaúcho engloba vestimenta, hábitos alimentares (cujo prato principal é o churrasco e a bebida o chimarrão, que o gaúcho toma ao amanhecer e ao fim da tarde, depois das lides do campo), o costume de usar bombachas e um lenço branco ou vermelho amarrado ao pescoço, chapéu, botas, esporas, faca e laço para o trabalho com o gado. Juntamente com as suas características, foi estilizado e cultuado na literatura como "o centauro dos pampas" e "monarca das coxilhas". Flores (2004) acredita que tenha sido fácil idealizar o gaúcho atribuindo a ele características inerentes a heróis, tais como a lealdade, a coragem, bastando buscar essas qualidades que eram necessárias ao gaúcho, no seu dia-a-dia nos pampas: "O símbolo do gaúcho tornou-se coletivo porque usa arquétipos arcaicos que foram elaborados cuidadosa e conscientemente na mitologia de todas as civilizações ao longo dos séculos: coragem, ousadia, alegria, indiferença pela morte, honestidade, honra, amor ao pago, machismo, lealdade." (FLORES, 2004, p. 2)

Essas características se adequaram perfeitamente aos codinomes "monarca das coxilhas" e "centauro dos pampas". Assegura-nos Flores (2004): "O resultado é um sentimento muito estereotipado, que emigrou da letra de forma para outras modalidades de arte e segundo o qual o habitante da Campanha encarna sempre a galhardia, a coragem, a lealdade, o desprendimento de uma criatura perfeita. Esse foi o molde em que se fundiu o monarca das coxilhas e o centauro dos pampas.” (FLORES, 2004, p. 2) Esses codinomes agregam-se às imagens formadoras do homem dos pampas gaúchos.

\section{Lá vem o Rio Grande a cavalo- que bonito que ele é ${ }^{6}$}

Assim, o cavalo tornou-se companheiro inseparável do gaúcho. Com o tempo essa relação cotidiana homem-cavalo passou a ser projetada na literatura e o gaúcho passou a ser conhecido pela antonomásia de centauro. O folclore do Rio Grande dignifica a magnitude da alma do povo gaúcho, legendário na história e amante fiel do seu bravo companheiro: o cavalo. Assim Vellinho (1962) identifica a aproximação do gaúcho e do cavalo:

Do cruzamento do europeu com o índio resultou a matéria-prima de que sairia o gaúcho. Mas o novo tipo social só alcançaria sua configuração peculiar, aquela com se projetou na história e na literatura, quando se fundiu com o cavalo para multiplicar seus contatos com o pampa e com as manadas selvagens, na violenta faina de todos os dias" (VELLINHO, 1962, p. 14-15)

O cavalo sempre foi exaltado pelos gaúchos rio-grandenses. A letra da música nativista "Florêncio Guerra" de Luiz Carlos Borges conta quando o "patrão disse a Florêncio que desse um fim no matungo", este "afiou a faca para sangrar seu cavalo," amigo de muito tempo, desde que "seu cavalo pisava estrelas nas serras pra chegar antes dos galos. Pensando no seu cavalo, parceiro pelas lonjuras, na calma das campereadas, barco em tardes serenas e um tigre numa por-

\footnotetext{
${ }^{6}$ Lá vem o Rio Grande a cavalo / que bonito que ele é: versos da letra da música Entrando No M'bororé, de Elton Saldanha, cantor gaúcho. Composição: João Sampaio/Elton Saldanha Disponível no link: https://www.letras.mus. br/elton-saldanha/324184/. Acessado em 12.03.2016.

${ }^{7}$ Cavalo velho, que ficou totalmente imprestável.
} 
teira, pechando boi pelas primaveras, sem mango... sem nazarenas, Florêncio afiou a faca" e sangrou o cavalo. A seguir, com a mesma faca, sangra a si mesmo.

Assim, o homem morre com seu cavalo, não se distinguindo qual era o homem, qual o cavalo. Os dois, mortos, Florêncio sobre o cavalo, são confundidos com um centauro, metade animal- metade homem: "Acharam Florêncio morto/ Por cima do seu cavalo / Alguém que andava no campo / Viu um centauro sangrado / Caídos no mesmo barro / Voltando pra mesma terra / Que deve tanto ao cavalo /E tanto a Florêncio Guerra /(Luiz Carlos Borges)

O Rio Grande do Sul tem um débito até hoje não esquecido por aqueles que cantam e idolatram o gaúcho e o cavalo, fundidosnum só ser: o Centauro dos Pampas, e que se agregam à imagem do homem que trabalha nos campos.

\title{
Centauro
}

Centauro, segundo The Watkins Dictionary of Symbols, é:

\begin{abstract}
um símbolo de homens presos por seus impulsos mais básicos, especialmente luxúria, violência e embriaguez. Exibido pela primeira vez na arte grega, como um homem com a parte traseira de cavalo, mas mais tarde, como um cavalo com um torso humano; o centauro foi mitificado provavelmente tendo como base bandos de cavaleiros que viviam sem leis, oriundos das montanhas de Tessália. De acordo com um mito de Ixion mortais violaram a nuvem Nephele acreditando que ela fosse a deusa Hera, esposa de Zeus. Nephele deu à luz ao centauro, monstro que cruzando com éguas, deu origem aos centauros. Dessa linhagem bestial, os centauros se tornaram estupradores, bêbados, selvagens, que muitas vezes eram mostrados com rostos angustiados e lutando sem sucesso contra as forças da lei e da ordem. Como tal, eles representam paixãosensual, adultério e heresia na iconografia cristã. Uma alternativa visando humanizar o mito foi incutir a eles uma moralidade superior fazendo crer que os centauros descendem de Cronos. Entre os centauros que seriam considerados superiores estaria Quíron, sábio professor, médico e amigo de Hércules (na mitologia romana Hércules, com uma fflecha atingiu este centauro por acidente. O sacrifício de Quíron deu sua própria imortalidade para libertar o herói. Prometeu rendeu-lhe um lugar paradisíaco ao sul da constelação Centaurus. Isso pode ser interpretado como uma metáfora para o triunfo da mente sobre as forças instintivas, gerando tensão dentro da imagem dinâmica do centauro. Estes híbridos aparecem no mito védico como a virilidade física combinada com dons intelectuais. ${ }^{8}$ (WATKINS, p. 35)
\end{abstract}

Em "O gaúcho" (Alencar,1973), o morador do Rio Grande do Sul aparece então relacionado ao seu cavalo, "o amor que toma o homem à cavalgadura, sabia o gaúcho que é retribuído sinceramente" (Alencar, 1973, p. 39). Esta é uma das primeiras associações na literatura brasileira da imagem do gaúcho ao centauro. O personagem Manoel Canho assim se refere à junção do homem ao cavalo: "O gaúcho tem um elemento, que é o cavalo. A pé está em seco, faltam-lhe as asas. Nele se realiza o mito da antiguidade: o homem não passa de um busto apenas; seu corpo consiste no bruto. Uni as duas naturezas incompletas: este ser híbrido é o gaúcho, o centauro da América." (ALENCAR, 1973, p. 28)

\footnotetext{
8 A symbol of man trapped by his baser impulses, especially lust, violence and drunknness. First shown in Greek art as a man with the hindquarters of a horse, but later a horse with human torso and head, the centauro probably mythologized Lawless bando $\mathrm{f}$ horsemen from the mountains of Thessaly. According to the myth, the mortal Ixion ravished the cloud Nephele believing her to be the goddess Hera, wife of Zeus; Nephele duly gave birth to the monster Centaurus whose bestiality with mares in turn produced the centaurs. With this srry lineage, the centauro became wild, drunken rapists, often shown with anguished faces and battling unsuccessfully against the forces of law and order. As such they represent sensual passion, adultery, and heresy in Christian iconography. An alternative, humanizing myth introduced a race of morally superior centaurs with descended from Cronos, among them Chiron, wise teacher, doctor and friend of Herakles(in Roman myth, Hercules), whose poisoned arrow struck this centauro by accident. Chiron's sacrifice of his own immortality to free the hero Prometeus earned him a heavenly place as the Southern constellation, Centaurus. This can be interpreted as a metaphor for the triumph of mind over instinct.
} 
O homem adquire características humanas e animais num só ser, associando humanidade à selvageria, aproximando-se do ser grego, mitológico, do centauro. Como explica Carine Daniel:

A relação entre o homem e o cavalo não é de uma união literalmente carnal, mas de uma complementação simbólica, representando a figura do centauro, que é um herói e um mito na história e na literatura do Rio Grande do Sul. O cavalo empresta ao homem seu instinto de ser livre, sua velocidade, sua elegância, enfim, a sua majestade. Homem e cavalo unidos formam o centauro dos pampas, habitando esse lugar tão diferente das montanhas e florestas da mitologia grega, representando não só a união do homem com o cavalo, mas também a união desse ser unificado com a terra que habita e defende. (DANIEL, 2007, p. 27)

Assim "centauro dos pampas" começou a ser usado para simbolizar o mito do gaúcho unido ao seu cavalo:

Havia entre o gaúcho e os cavalos verdadeiras relações sociais[...] o cavalo era para o gaúcho um próximo, não pela forma, mas pela magnanimidade e nobreza das paixões. Entendia ele que Deus tinha feito os outros animais para vários fins recônditos em sua alta sabedoria, mas o cavalo, esse Deus criara exclusivamente para amigo e companheiro do homem. (Alencar, 1973, p. 28)

Erico Verissimo trata de aproximar os homens do pampa gaúcho aos cavalos até mesmo fazendo alguns deles adquirir traços equinos:

Não levar desaforo para casa, saber montar bem e ter tomado parte pelo menos numa guerra eram as glórias supremas daquela gente meio bárbara que ainda bebia água em guampas de boi. E a importância que o cavalo tinha na vida da Província! Para os continentinos o cavalo era um instrumento de trabalho e ao mesmo tempo uma arma de guerra, um companheiro, um meio de transporte; para alguns gaúchos solitários as éguas serviam eventualmente de esposa. Winter conhecia ali homens que à força de lidar com cavalos começavam já a ter no rosto traços equinos. (VERISSIMO, 1995b, p. 363)

Os centauros são aqui associados ao mito do gaúcho que começou a ser chamado de "centauro do pampa" e "centauro das coxilhas" aquele que "[e]mergia, do meio dos animais, vigoroso, exuberante, mítico, como a encarnação da força dominadora" (Marobin, 1985, p. 67). Gaúchos e centauros têm suas imagens definitivamente aproximadas. O homem rio-grandense transforma-se no "centauro dos pampas, por sua identificação plena com o animal, assemelhando-se assim à entidade mitológica de corpo metade cavalo-metade homem" (HOHLFELDT, 1996, P.20) ambos evidenciam uma junção homem-cavalo: "Os antigos apreciavam muito o cavalo [...] o centauro é o único dos monstros mitológicos da antiguidade ao qual eram atribuídas também boas qualidades [...] e eram admitidos na companhia dos homens". (BULFINCH, 2000, p. 156). Assim, os centauros eram, na mitologia grega, vistos como monstros, metade homem,

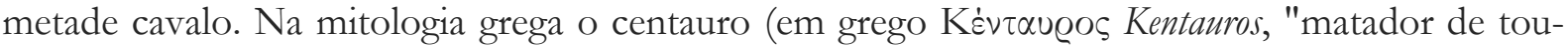

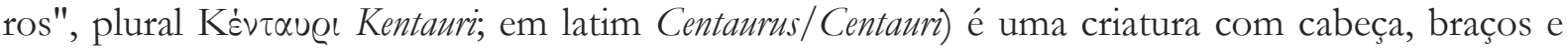
dorso de um ser humano e com corpo e pernas de cavalo.

Os centauros viviam nas montanhas de Tessália e repartiam-se em duas famílias: Os filhos de Íxion e Nefele simbolizavam a força bruta, insensata e cega. Alimentavam-se de carne crua. Alternativamente, consideravam-se filhos de Kentauros (o filho de Íxion e Nefele) e algumas éguas magnésias ou de Apolo e Hebe.

\section{Capitão Rodrigo Cambará - um centauro em Santa Fé}

Conta-se que Íxion planejava manter relações sexuais com Hera, mas Zeus, o marido de Hera, evitou o fato modelando uma nuvem (nefele, em grego) em forma de Hera. Assim Nefele foi confundida com Hera e estuprada, gerando o centauro. Mais tarde, visando humanizar o mito, 
foi infundida a ideia de que os centauros descendiam de Cronos. Entre os centauros que seriam considerados superiores estaria Quíron, sábio professor, médico e amigo de Hércules Quíron, amigo de Hércules, representavam, ao contrário, a força aliada à bondade, a serviço dos bons combates. Os centauros são muito conhecidos pela luta que mantiveram com os Lápitas, provocada pelo seu intento de raptar Hipodâmia no dia da sua boda com Pirítoo, rei dos Lápitas e também filho de Íxion. Conta a mitologia que os centauros foram convidados para o casamento de um humano e tentaram violentar a noiva depois de consumir uma quantidade excessiva de vinho: "[...] estavam entre os convidados, no casamento de Píritos com Hipodâmia. Na festa, Eurátion, um dos centauros, tendo-se embriagado com vinho, tentou violentar a noiva; os outros seguiram seu exemplo, provocando um terrível conflito, no qual vários deles foram mortos. Nem todos os centauros, porém, eram semelhantes aos grosseiros convidados de Píritos." (BULFINCH, 2000, p. 156)

Consta também, na mitologia grega, que os centauros estão ligados a outros casos de raptos de mulheres. "Um ou vários centauros ainda apresentam em outras lendas sobre abduções (raptos), Eurytion tentou raptar Mnesimache de Heracles, que estava prometida em casamento a ela." (GRIMAL, 2000, pp. 94-95)9

A intenção aqui é aproximar o comportamento de Rodrigo Cambará aos centauros mitológicos durante o casamento de Píritos, para o qual foram convidados. Rodrigo foi ao casamento da filha de um cidadão de Santa Fé, Joca Rodrigues e, bebendo vinho, observava os locais divertindo-se e dançando no casamento e "de seu lugar Rodrigo cocava Bibiana com olhos famintos" (VERISSIMO, 1995, p. 163). Depois do casamento na capela houve jantar e baile no terreiro da casa de Joca Rodrigues. Rodrigo, ainda que Bibina estivesse acompanhada, aproxima-se e dirigese diretamente a ela convidando-a para dançar, obviamente desrespeitando o acompanhante e os costumes locais. Cambará forjou uma forma de vida sob a qual o estigma de liberdade sinaliza seus passos. Tal liberdade era vista como inédita em Santa Fé. Todos viviam de acordo com normas estritas e dentro das convenções sociais do povoado. Rodrigo tinha sentimentos violentos e por pouco não agia como um dos centauros no casamento de Píritos, sentindo-se tentado a levar Bibiana consigo:

Só lamentou que não pudesse virar a mesa com um pontapé, dar um empurrão em Bento, tomar Bibiana pelo braço, montar a cavalo, levar a moça na garupa e ir deitar-se com ela em meio do campo, sob aquelas mesmas estrelas que o haviam acompanhado em tantas campanhas. (VERISSIMO, 1995, p. 167, grifo nosso)

Podemos aqui dizer que Rodrigo gostaria de ter possuído Bibiana sem ter tido que passar pelo casamento: "Depois - concluiu ele com certa irritação - parecia que só poderia dormir com a moça se casasse com ela..." (VERISSIMO, 1995, p. 23). A obrigação de casar contrariou-o um pouco. Podemos também dizer que Rodrigo teve que lutar contra si mesmo e contra seus instintos selvagens para não raptar Bibiana e leva-la consigo, já que esta não seria a primeira vez que faria isso durante sua vida. Ele colocava as mulheres na garupa do cavalo, ficava com elas o tempo que quisesse e depois as largava em qualquer lugar:

Achou melhor não continuar, porque não queria perder a amizade de Juvenal. Ia dizer que se Bibiana o amasse, ele a tiraria de casa e a levaria para longe na garupa do cavalo. Já tinha feito isso com outras mulheres, em outros lugares. Deixava-as depois no caminho, quando se cansava delas. Mas com Bibiana ia ser diferente. Queria a moça para esposa. Desejava ter uma casa e filhos, muitos filhos. (VERISSIMO, 1995, p. 140, grifo nosso)

O vinho foi a base do conflito instaurado na festa de casamento, tanto na casa de Joca

\footnotetext{
9 "One or several Centaurs still feature in other legends concerning abductions, Eurytion tried to abduct Mnesimache from Heracles, who was betrothed to her" (Grimmal, 2000, pp. 94-95).
} 
como na casa de Píritos, segundo a mitologia. Os centauros não bebiam com frequência: "Eles não eram acostumados a beber vinho e logo ficaram intoxicados. estavam bêbados." ${ }^{10}$ (GRIMMAL, 2000, p. 95). Também em Santa Fé, fruto da bebida, Rodrigo ostenta uma atitude desafiadora:

A bebida lhe dera uma tontura boa e quando caminhava ele tinha a impressão de que o chão the fugia. Mas não estava tão embriagado que não compreendesse que estava embriagado e que se não se contivesse poderia fazer alguma asneira. Não queria de modo algum entornar o caldo. Desejava falar com Bibiana sem precisar brigar com ninguém. Se provocasse algum escândalo talvez perdesse a moça para sempre. (VERISSIMO, 1995, p. 170)

Ele não queria faz̧er barulho, mas sempre acabava fazendo. Essa afirmação era recorrente nele:

O padre Lara acendeu um cigarro e olhou em torno. Depois, lançando um olhar enviesado para Rodrigo, perguntou: - Quantos copos de vinho bebeu, capitão? - Uns dez... - Por que não vai dar um passeio na praça e depois volta pra cá? - Está com medo que eu faça alguma loucura? - Para lhe ser franco, estou. - Não se preocupe. Estou enxergando mui claro. Não quero fazer barulho. (VERISSIMO, 1995, pp. 171-172, grifos nosso)

Depois de dez copos de vinho, Rodrigo não podia dizer que não estava alterado. Rodrigo não queria fazer barulho, mas fez. Houve muita confusão na noite desse casamento.

É-nos difícil aferir relação entre Rodrigo e Dona Paula, esposa de Nicolau, assédio ou estupro, mas podemos considerar que ele desrespeitou a casa de $\mathrm{N}$ icolau ao manter relações com Dona Paula na casa do homem que confia em alugar um quarto para um estranho: "O Nicolau tinha saído de casa e ali do outro lado do tabique sua mulher estava numa cama... Não era nem muito moça, nem bonita e nem podemos considerar que ela permitiu a aproximação previamente. Mas era uma fêmea" (Veríssimo, 1995, p. 110). "Ele sabia que a china o evitava, como se o temesse. Espiava-o sempre de longe, com seus olhos de animal assustado" (VERISSIMO, 1995, p. 110, grifo nosso).

Pode ser que ela realmente o temesse, pode ser que o olhasse por sentir-se fascinada, pode ser até que o quisesse; o certo é que não parece que tenha dado demonstração anterior de que o queria e que essa primeira relação não foi consensual:

E, fosse como fosse, era uma mulher. De pé, junto da cama, Rodrigo ouvia o rascar das chinelas da companheira do Nicolau. Sabia que para ir à cozinha Paula tinha de passar pelo seu quarto. Entreabriu a porta e ficou esperando de luz apagada. E quando o vulto da mulher passou, Rodrigo murmurou: Dona Paula... Ela estacou, muda. Ele a segurou pelos ombros e puxou-a para dentro do quarto. Sentiu que ela tremia toda, como se estivesse com sezões, mas não fez nenhum gesto, não disse a menor palavra. Arrastou-a para a cama. (VERISSIMO, 1995, pp. 110-111)

Uma forte e instigante essência do mito despontou quando se juntou a figura do gaúcho com o seu cavalo. O gaúcho aproxima-se do mito clássico, da figura mítica do centauro: figura meio humana, meio animal, meio mágica, corajoso, guerreiro, atraente, com grande apelo sexual e sedutor das mulheres, mas, na mesma medida irracional, instintivo, ligado ao rapto, às lutas, às bebidas, ao animalesco e ao selvagem. Por essas características Rodrigo Cambará aproxima-se dos centauros. Quando bebe em demasia, desrespeita a casa em que foi convidado a estar, ignora as convenções sociais do meio ao qual tenta inserir-se, quando se sente tentado a raptar Bibiana e colocá-la na garupa de seu cavalo e levá-la para longe.

\footnotetext{
10 "they were unused to drinking wine and soon became intoxicated." (GRIMMAL, 2000, p. 95).
} 


\section{Considerações finais}

Essa associação da figura do gaúcho à imagem do centauro foi, provavelmente, fruto da convivência diária desse homem com os cavalos, manadas selvagens que existiam em abundância, nos pampas gaúchos, já que, a princípio, os gaúchos, mestiços resultantes do cruzamento de europeus com índios, atirados a si mesmos, sem leis sem ordens, à margem da sociedade que se criava, viviam nos campos do Rio Grande do Sul como bandoleiros. Acostumou-se a usar, como montaria, o cavalo que andava livremente pelos pastos em grandes manadas, como meio de transporte nas grandes distâncias das planícies descampadas. Quando o gado começou a tornar-se valioso pelo seu subproduto, principalmente o couro que começava a ser valorizado, o cavalo ganhou outra utilidade; era imprescindível para arrebanhar essas manadas que abundavam nos campos ainda indômitas e ariscas. O gaúcho e o cavalo tornaram-se companheiros inseparáveis; acabando por unir sua figura à imagem do centauro mitológico.

Ainda mais, Rodrigo Cambará teve aqui sua figura aproximada aos centauros pelo imenso apetite sexual e pelo desrespeito a casa de outros homens. Também podemos aproximá-los enquanto construção ideológica: capitão Rodrigo, enquanto imagem idealizada de guerreiro livre em suas idas e vindas, tendo seu cavalo por companheiro fiel, capaz de levá-los às guerras e libertálos das amarras sociais quando essas ficavam muito apertadas para seu espírito aventureiro. $O$ centauro se aproxima dessa idealização por significar o homem acompanhado de suas inseparáveis companhias, os cavalos. Tais imagens estão até hoje cristalizados na cultura popular, sancionados e acolhidos pelos tradicionalistas, pelas canções, romances, lendas e histórias do Rio Grande do Sul.

A criação do mito do herói, sua importância para a cultura rio-grandense pode ter feito com que o personagem Rodrigo Cambará tomasse a forma de herói aos olhos do receptor ao receber essa personagem literária; a literatura ajudou na busca e no cultivo dessa memória e identidade, projetando o "Centauro dos pampas" que vivia na época do campo aberto, do horizonte infinito onde podia andar horas a cavalo, pelos pampas gaúchos. Destarte, dentro dos conflitos entre as masculinidades representadas na narrativa, Rodrigo deixa o campo de batalha pela masculinidade hegemônica para figurar como uma masculinidade mítica, representada pelo mito do gaúcho-centauro.

\section{Referências}

ALENCAR José de. O Gaúcho. Obras completas de José de Alencar, Volume IV, 1973

BULFINCH, Thomas. O livro de ouro da mitologia. Histórias de deuses e heróis. 9. Edi. Rio de Janeiro: Ediouro, 2000.

DANIEL, Carine. A mitificação e a desmitificação do gaúcho em o vaqueano e porteira fechada, respectivamente. Disponível no link: http://biblioteca.unilasalle.edu.br/docs_online/tcc/graduacao/letras/ 2007/cdaniel.pdf, acessado em 06.12.2016.

FLORES, Moacyr. O mito do gaúcho. Correio Rio-grandense. Caxias do Sul: São Miguel, 2004

FLORES, Moacyr. Revolução Farroupilha. UFRGS, 1994

GRIMAL, Pierre. Centaurs. The dictionary of classical mythology.Translated by A.R. Maxwell-Hyslop. Oxford: Blackwel, 2000. Translation of: Dictionnaire de La Mythologie Grecque et Romaine. p. 94-95.

HOLFELDT, Antônio. Literatura e vida social. 2. ed. Porto Alegre: Editora da Universidade, 1996. MAROBIN, Luis. A literatura no Rio Grande do Sul-aspectos temáticos e estéticos, Martins Livreiro Editor, Porto Alegre, 1985

PESAVENTO, Sandra. História do Rio Grande do Sul. Porto Alegre: Mercado Aberto, 1982.

REICHEL, Heloísa Jochims. A identidade Sul-Riograndense no imaginário de Erico Verissimo.

https://periodicos.unifap.br/index.php/letras

Macapá, v. 9, n. 2, $2^{\circ}$ sem., 2019 
In: GONÇALVES, Robson Pereira (org.) O tempo e o vento 50 anos. Santa Maria: Editora da UFSM, 2000, pp. 207-218.

SILVA, A. F. da; SANTOS, P. B. O mito do gaúcho e seu redimensionamento em "trezentas onças", de Simões Lopes Neto. II Colóquio Leitura e Cognição, 2005, Santa Cruz do Sul. Disponível em: http://www.unisc.br/portal/images/stories/mestrado/letras/coloquios/ ii/mito_o_gaucho.pdf. Acessado em 05.03.2016)

TRESIDDER, Jack. The Watkins Dictionary of Symbols, Watkins publishing - Londonhttps://books.google.com.br/books?id=_DEsRyoy41MC\&pg=PT61\&dq=Centaurs + rapiss\&hl $=$ pt-BR\&sa $=$ X\&ei $=$ WLgFVPCYNs2-sQS2goGgDQ\# $\mathrm{v}=$ onepage $\& \mathrm{q}=$ Centaurs $\% 20$ rapists $\& \mathrm{f}=$ true. Acessado em 05.03.2016

VELLINHO, Moisés. O Rio Grande e o prata: contrastes, Coleção: Cadernos do Rio Grande. Editora: IEL Instituto Estadual do Livro RS, 1962.

VERISSIMO, Erico. O tempo e o vento, O continente . 31 edição, Globo S.A.,1995

VERISSIMO, Erico. O tempo e o vento, O continente II. 31 edição, Globo S.A.,1995b.

Envio: 30/08/2019

Aceite: 07/12/2019 